\title{
Genetic Variability, Heritability and Genetic Advance in Bread Wheat (Triticum aestivum L.) Genotypes
}

\author{
Jagdish Prasad*, Abhay Dashora, Deeksha Chauhan, \\ Sandeep Kumar Bangarwa and K. Nesara \\ Department of Genetics and Plant Breeding, RCA, MPUAT, Udaipur, India \\ *Corresponding author
}

\begin{abstract}
A B S T R A C T
Keywords

Wheat, Genetic variability, GCV, PCV, Heritability, Genetic advance

Article Info

Accepted:

10 September 2020

Available Online:

10 October 2020

The Present investigation was carried out using 50 bread wheat genotypes at Instructional Farm, Rajasthan College of Agriculture, Udaipur during Rabi, 2019-2020 in randomized block design with three replications. Analysis of variance revealed significant difference between genotypes for all the characters studied. Sufficient variability was present in the genotypes under study for all the characters indicating sufficient genetic variability among the genotypes. Phenotypic coefficient of variation (PCV) was marginally higher than the respective genotypic coefficient of variation $(\mathrm{GCV})$ for all the characters indicating thereby that there is negligible influence on the characters by the environment. GCV was high for grain yield per plant, grain weight per spike, biological yield per plant, number of grains per spike and number of effective tillers per plant. High PCV was observed for grain weight per spike followed by grain weight per plant, biological yield per plant, number of grains per spike, number of effective tillers per plant and length of main spike. High broad sense heritability along with high genetic advance as percentage of mean were obtained for number of grains per spike, biological yield per plant days to $50 \%$ heading and plant height.
\end{abstract}

\section{Introduction}

Wheat (Triticum aestivum L.; $2 \mathrm{n}=6 \mathrm{x}=42$ ), belongs to the family Poaceae, is one of the most important staple food amongst major cereals of the world, occupying $17 \%$ of crop acreage worldwide, feeding about $40 \%$ of the world population and provide $20 \%$ of the total food calories and protein in human nutrition. Wheat originated from South West Asia. It is a self-pollinated crop and an annual plant having height about 60 to $150 \mathrm{~cm}$ long.
Inflorescence of wheat is erect terminal spike of spikelets called as ear or head of grains, flower grouped into 15-20 spikelets arranged alternatively on rachis, each spikelets with 2-6 flowers out of which only 2-3 flowers are fertile and produce grains. Wheat grain contains 2-3\% germ, 13-17 \% bran (outer layers of wheat grain) and 80-85\% mealy endosperm on dry matter basis (Belderok et al., 2000). Bran is rich in vitamin B and minerals. The endosperm mainly contains food reserves which are needed for growth of 
the seedling. Endosperm contains fats (1.5\%) and proteins (13\%), albumins, globulins and the major proteins of the gluten complexglutenins and gliadins-proteins that will form the gluten at dough stage. Globally, wheat (Triticum spp.) is grown in about 220.83 million hectares holding the position of highest acreage among all crops with annual production hovering around 769.31 million tones (USDA, 2020). In India, it is grown in area of 30.55 million hectares with a production of 107.18 million tones and productivity of $3508 \mathrm{~kg} / \mathrm{ha}$. In Rajasthan, it is grown-up in an area of 3.02 mha. with a production and productivity of 10.57 million tones and $3501 \mathrm{~kg} / \mathrm{ha}$., respectively (Anonymous, 2020). Grain yield in wheat is a complex character and is depend on its component traits. For genetic manipulation of grain yield, quality and other characters in wheat, there is a need to examine the nature of genetic variability for the yield related attributes and quality traits. Estimation of genotypic coefficient of variation (GCV) and phenotypic coefficient of variation (PCV) helps to choose the potential genotype and heritability along with genetic advance would be more useful tool in predicting the resultant effect for selection of best genotypes for yield. Keeping these things in the view, the present investigation was made to assess genotypes with the objectives, to estimate the variability, heritability and genetic advance for yield and yield components traits in wheat.

\section{Materials and Methods}

The experimental plant material comprised of 50 bread wheat genotypes were taken from AICRP on Wheat located at Department of Genetics and Plant Breeding, Rajasthan College of Agriculture, MPUAT, Udaipur. Udaipur is located at latitude of $24^{\circ} 35^{\prime}$ North and longitude of $37^{\circ} 42^{\prime}$ East and at an elevation of 582.17 meters above mean sea level. Soil texture of research field was clay loam with $\mathrm{pH}$ 7.6. The experiment was laid out in randomized block design (RBD) with 3 replications, each replication and each genotype sown in two rows of five meter length spaced at $25 \mathrm{~cm}$ from row to row and $10 \mathrm{~cm}$ from plant to plant. The recommended package of practices was adopted for raising the healthy crop. Observations for all the traits were recorded on five randomly selected plants of each entry in each replication while observations for days to 50 per cent heading and days to maturity were recorded on plot basis. Statistical analysis:- To test the difference among the genotypes, the analysis of variance was worked out separately for each character as per method suggested by fisher (1954) and using standard statistical procedure given by Panse and Sukhatme (1954). Genotypic coefficient of variation (GCV) and Phenotypic coefficient of variation $(\mathrm{PCV})$ were calculated as per the standard formula suggested by Burton (1952).

$\operatorname{GCV}(\%)=\frac{\sqrt{\mathrm{Vg}}}{\mathrm{X}} \times 100$

Where,

$\mathrm{Vg}=$ genotypic variance

$\mathrm{X}=$ general mean of the character under investigation

$\operatorname{PCV}(\%)=\frac{\sqrt{\mathrm{Vp}}}{\mathrm{X}} \times 100$

$\mathrm{Vp}=$ phenotypic variance

$\mathrm{X}=$ general mean of the character under investigation

Heritability $\left(\mathrm{h}^{2}\right)$ was calculated in broad sense by using the following formula given by Johnson et al., (1955).
$\mathrm{h}^{2}$
$(\%)=\frac{\mathrm{Vg}}{\mathrm{Vp}} \times 100$ 
Where,

$\mathrm{h}^{2}=$ Heritability in broad sense

$\mathrm{Vg}=$ Genotypic variance

$\mathrm{Vp}=$ Phenotypic variance

Genetic gain (GG) is the genetic advance expressed as per cent of mean. It was estimated by using the formula of Lush (1945) and Johnson et al., (1955).

$\mathrm{GG}(\%)=\frac{\mathrm{GA}}{\mathrm{X}} \times 100$

G.A $=$ Genetic advance $=\frac{\mathrm{KVg}}{\sqrt{\mathrm{Vp}}}$

$\mathrm{X}=$ general mean of the character under investigation

Where,

$\mathrm{K}=$ selection differential at 5 per cent selection intensity i.e. 2.06

$\mathrm{Vg}=$ genotypic variance

$\mathrm{Vp}=$ phenotypic variance

\section{Results and Discussion}

Analysis of variance (ANOVA) for all the characters viz., days to 50 per cent heading (days), days to maturity (days), plant height (cm), No. of effective tillers per plant, No. of spikelets per plant, length of main spike $(\mathrm{cm})$, No. of grains per spike, grain weight per spike(g), 1000 grains weight (g), grain yield per plant $(\mathrm{g})$, biological yield per plant $(\mathrm{g})$, harvest index $(\%)$, sedimentation value $(\mathrm{ml}) \&$ protein content $(\%)$ exposed significant mean sum of squares due to genotypes for all the characters studied indicating presence of sufficient genetic variation among all the genotypes. The mean sum of squares due to replication was found to be non-significant for all characters studied, Table 1. High magnitude of GCV were observed for grain yield per plant $(17.51 \%)$ followed by grain weight per spike $(17.38 \%)$ biological yield per plant $(15.83 \%)$ and number of grains per spike $(14.83 \%)$. Low magnitude of GCV observed for days to maturity $(3.23 \%)$ and protein content $(3.76 \%)$.

Table.1 Mean square for RBD in individual environment

\begin{tabular}{|l|l|r|r|c|}
\hline SN & Characters & Replication [2] & $\begin{array}{r}\text { Genotype } \\
{[49]}\end{array}$ & $\begin{array}{l}\text { Error } \\
{[98]}\end{array}$ \\
\hline 1 & Days to 50 \% heading & 3.78 & $88.93^{* *}$ & 3.11 \\
\hline 2 & Days to maturity & 4.41 & $56.08^{* *}$ & 4.50 \\
\hline 3 & Plant height (cm) & 18.48 & $141.86^{* *}$ & 9.85 \\
\hline 4 & Number of effective tillers per plant & 0.23 & $3.32 * *$ & 0.41 \\
\hline 5 & Number of spikelets per spike & 0.55 & $7.89 * *$ & 0.78 \\
\hline 6 & Length of main spike (cm) & 0.68 & $2.99 * *$ & 0.44 \\
\hline 7 & Number of grains per spike & 11.63 & $257.67 * *$ & 7.94 \\
\hline 8 & Grain weight per spike (g) & 0.20 & $1.09 * *$ & 0.14 \\
\hline 9 & 1000 grain weight (g) & 5.96 & $35.64 * *$ & 3.95 \\
\hline 10 & Grain yield per plant (g) & 2.51 & $23.85 * *$ & 1.35 \\
\hline 11 & Biological yield per plant (g) & 17.79 & $147.14 * *$ & 6.32 \\
\hline 12 & Harvest Index $(\%)$ & 12.91 & $23.29 * *$ & 6.60 \\
\hline 13 & Sedimentation value (ml) & 0.35 & $25.17 * *$ & 0.92 \\
\hline 14 & Protein $(\%)$ & 0.01 & $0.72 * *$ & 0.24 \\
\hline
\end{tabular}

$*$ and $* *$ indicates significant level at $5 \%$ and $1 \%$ respectively. [ ] Degrees of freedom 
Table. 2 Genetic variability parameters for yield and its contributing traits in wheat

\begin{tabular}{|c|c|c|c|c|c|c|c|c|c|}
\hline \multirow{2}{*}{$\begin{array}{l}\text { S. } \\
\text { No }\end{array}$} & \multirow[t]{2}{*}{ Characters } & \multirow[t]{2}{*}{ Means } & \multicolumn{2}{|c|}{ Range } & \multirow{2}{*}{$\begin{array}{l}\text { GCV } \\
(\%)\end{array}$} & \multirow{2}{*}{$\begin{array}{l}\text { PCV } \\
(\%)\end{array}$} & \multirow{2}{*}{$\begin{array}{c}\mathbf{H}_{(\mathrm{bs})}^{2} \\
(\%)\end{array}$} & \multirow{2}{*}{$\begin{array}{l}\text { Genetic } \\
\text { Advance }\end{array}$} & \multirow{2}{*}{$\begin{array}{c}\text { Genetic } \\
\text { Gain }\end{array}$} \\
\hline & & & Min. & Max. & & & & & \\
\hline 1 & Days to $50 \%$ headin & 81.70 & 67.00 & 92.67 & 6.55 & 6.89 & 90.20 & 10.46 & 12.81 \\
\hline 2 & Days to maturity & 128.55 & 114.67 & 134.00 & 3.23 & 3.62 & 79.27 & 7.61 & 5.92 \\
\hline 3 & Plant height $(\mathrm{cm})$ & 97.58 & 79.60 & 110.40 & 6.80 & 7.52 & 81.72 & 12.35 & 12.66 \\
\hline 4 & $\begin{array}{l}\text { Number of effective tillers } \\
\text { per plant }\end{array}$ & 9.01 & 6.47 & 10.80 & 10.93 & 13.02 & 70.52 & 1.70 & 18.91 \\
\hline 5 & $\begin{array}{l}\text { Number of spikelets per } \\
\text { spike }\end{array}$ & 18.68 & 14.10 & 21.23 & 8.24 & 9.50 & 75.15 & 2.75 & 14.71 \\
\hline 6 & Length of main & 10.27 & 8.20 & 12.13 & 8.96 & 11.06 & 65.72 & 1.54 & 14.97 \\
\hline 7 & Number of grains per spike & 61.52 & 37.10 & 76.83 & 14.83 & 15.52 & 91.29 & 17.96 & 29.19 \\
\hline 8 & Grain Weight per spike (g) & 3.25 & 2.17 & 4.47 & 17.38 & 20.76 & 70.02 & 0.97 & 29.95 \\
\hline 9 & 1000 grain weight $(\mathrm{g})$ & 45.02 & 36.10 & 49.97 & 7.22 & 8.46 & 72.77 & 5.71 & 12.69 \\
\hline 10 & Grain yield per plant (g) & 15.64 & 10.97 & 20.57 & 17.51 & 19.02 & 84.74 & 5.19 & 33.20 \\
\hline 11 & $\begin{array}{l}\text { Biological Yield per plant } \\
\text { (g) }\end{array}$ & 43.29 & 31.40 & 56.73 & 15.83 & 16.86 & 88.13 & 13.25 & 30.61 \\
\hline 12 & Harvest Index (\%) & 36.15 & 31.12 & 42.80 & 6.53 & 9.65 & 45.76 & 3.29 & 9.09 \\
\hline 13 & Sedimentation Value (ml) & 37.58 & 32.03 & 42.90 & 7.57 & 7.98 & 89.83 & 5.55 & 14.77 \\
\hline 14 & Protein $(\%)$ & 10.59 & 9.50 & 11.53 & 3.76 & 5.97 & 39.69 & 0.52 & 4.88 \\
\hline
\end{tabular}

High magnitude of PCV were observed for grain weight per spike $(20.76 \%)$ followed by grain yield per plant (19.02\%), biological yield per plant $(16.86 \%)$ and number of grains per spike $(15.52 \%)$. Low magnitude of PCV observed for days to maturity $(3.62 \%)$, protein $(5.97 \%)$ and days to $50 \%$ heading. Heritability in broad sense was high for most of the characters studied except protein content (39.69 $\%)$ and harvest index (45.76\%). The highest heritability were observed for number of grains per spike $(91.29 \%)$ followed by days to $50 \%$ heading $(90.20 \%)$ and sedimentation values $(89.83 \%)$. High magnitude of genetic gain were observed for grain yield per plant $(33.20 \%)$ followed by biological yield per plant $(30.61$ $\%)$, grain weight per spike $(29.95 \%)$, number of grains per spike $(29.19 \%)$ and number of effective tillers per plant $(18.91 \%)$. Low magnitude of genetic gain was observed for protein content $(4.88 \%)$ and days to maturity (5.92 \%). In the present investigation the phenotypic coefficient of variation (PCV) was marginally higher than the respective genotypic coefficient of variation (GCV) for all the characters studied indicating that there is negligible influence on the expression of characters by the environment. The grain yield per plant depicted highest genotypic coefficient of variation followed by grain weight per spike, biological yield per plant, number of grains per spike and number of effective tillers per plant, while highest phenotypic coefficient of variation $(\mathrm{PCV})$ observed for grain weight per spike. The magnitude of GCV and PCV were low for days to maturity and protein content, Table 2. Earlier similar finding have been also reported by Yadav et al., (2014), Kumar et al., (2014) and Bhushan et al., (2013). The heritability estimates in broad sense were quite high for most of the characters indicated that strong genetic nature for all the traits. The higher heritability implied that selection for most of the traits might be effective in this set of genotypes. High estimates of heritability coupled with high genetic advance were 
observed for number of grains per spike, biological yield per plant, days to $50 \%$ heading and plant height which indicated that above characters was governed by additive gene action and as such expected to exhibit improvement by direct selection. Similar findings were also reported by Bhushan et al., (2013) and Nukasani et al., (2013).

\section{References}

Anonymous, 2019. Project Director's Report, ICAR-IIWBR, Karnal, Haryana, pp.1-3

Belderok, B., Mesdag, J., Mesdag, H. and Donner, D.A., 2000. Bread-making quality of wheat: a century of breeding in Europe. Springer Science \& Business Media. Pp. 15-20.

Bhushan, B., Bharti, S., Ojha, A., Pandey, M., Gaurav, S.S., Tyagi, B.S. and Singh, G. 2013. Genetic variability, correlation coefficient and path analysis of some quantitative traits in bread wheat. Journal of Wheat Research, 5(1): 21-26.

Burton, G.W. 1952. Quantitative inheritance in grasses. Proc. $6^{\text {th }}$ International Grassland Congress, 1: 277-283.

Burton, G.W., 1952. Estimating heritability in tall fescue from replicated clonal material. Agronomy Journal, 45(3), pp. 474-481.

Fisher, R.A. 1954. Statistical methods for research workers. $12^{\text {th }}$ Edition, Biological Monograph and Manuals, 5: 130-131.

Hanson, C.H., Robinson, H.F. and Comstock, R.E., 1956. Biometrical studies of yield in segregating populations of Korean lespedeza L. Agronomy journal, 48(6), pp.268-272.
Johnson, H.W., Robinson, H.F. and Comstock, R.E. 1955. Estimates of genetic and environmental variability in soybean. Agronomy Journal, 47: 14-318.

Kumar, N., Markar, S. and Kumar V. 2014. Studies on heritability and genetic advance estimates in timely sown bread wheat (Triticum aestivum L.). Bioscience Discovery, 5(1): 64-69.

Lush J. L. 1945. Intrawire correlation or regression of offspring on dam as a method of estimating heritability of characteristics. $33^{r d}$ Annual Procedure of American Society for Animal Production. 293-301.

Nukasani, V., Potdukhe, N.R., Bharad, S., Deshmukh, S. and Shinde, S.M. 2013. Genetic variability, correlation and path analysis in wheat. Journal of Wheat Research, 5(2); 48-51.

Panse V.G. and Sukhatme P.V., 1954. Statistical Method for Agriculture Workers. Indian Council of Agricultural Research New Delhi, pp 381.

Singh R.K. and Chaudhary B.D. 1977. Biometrical Methods in Quantitative Genetic Analysis, Kalyani Publishers, New Delhi, pp 266.

USDA (2019). United States Department of Agriculture. https://apps. fas.usda.gov /psclonline /circulars/production.pdf.

Yadav, S.K., Singh A.K., Baghel, S.S., Jarman, M. and Singh, A.K. 2014. Assessment of genetic variability and diversity for yield and it's contributing traits among CIMMYT based wheat germplasm. Journal of Wheat Research, 6(2): 154159.

\section{How to cite this article:}

Jagdish Prasad, Abhay Dashora, Deeksha Chauhan, Sandeep Kumar Bangarwa and Nesara, K. 2020. Genetic Variability, Heritability and Genetic Advance in Bread Wheat (Triticum aestivum L.) Genotypes. Int.J.Curr.Microbiol.App.Sci. 9(10): 868-872. doi: https://doi.org/10.20546/ijcmas.2020.910.103 